\title{
The use of resilience engineering tools for fault propagation mitigation in sociotechnical systems
}

\section{Felipe Gilberto Bratti Volken ${ }^{1}$, University of Taquari Valley, Lajeado, RS, Brazil}

\author{
Claudio Roberto do Rosário², University of Taquari Valley, Lajeado, RS, Brazil
}

\section{RESUMO}

Objetivo - Demonstrar uma aplicação da engenharia de resiliência, visando obter melhorias de produtividade e qualidade através da diminuição da variabilidade e da propagação de falhas nas funções produtivas do sistema sociotécnico objeto do estudo em uma usina de produção de concreto asfáltico.

Desenho / metodologia / abordagem - A abordagem utilizada foi o método de análise de ressonância funcional, no qual são entrevistados especialistas em um sistema sociotécnico, elicitando o conhecimento acerca dos aspectos de interação entre as funções produtivas. O conhecimento elicitado é alimentado no software FRAM Model Visualizer 0.4.1, que apresenta mapa gráfico do sistema e permite a análise do número de aspectos (NAC) de interação.

Resultados - A análise das NACs evidenciou que as funções controle laboratorial, queimador, secador e filtro de mangas apresentaram alto potencial de absorção de variabilidade, enquanto as funções de sistema de comando CLP e controle laboratorial apresentam alto potencial de propagação de falhas. Ambos os grupos foram examinados e explorado medidas dentro do escopo da engenharia de resiliência que potencializam seus papéis de mitigação da variabilidade dentro do sistema.

Originalidade / valor - A replicação da engenharia de resiliência explorada neste artigo viabiliza ganhos de produtividade e qualidade em sistemas sociotécnicos do mesmo segmento; já a aplicação da metodologia de análise ressonância funcional demonstrada pode trazer benefícios para futuros estudos em sistemas produtivos com interação entre pessoas e tecnologia.

Palavras-chave - Engenharia de resiliência, sistemas produtivos, sistemas sociotécnicos, FRAM.

\section{ABSTRACT}

Purpose - To demonstrate an application of resilience engineering, aiming to improve productivity and quality by decreasing variability and fault propagation in the production functions of a sociotechnical system, the object of the study, in an asphalt concrete production plant.

Design/methodology/approach - The approach used was the functional resonance analysis method, where experts in sociotechnical systems were interviewed, eliciting their knowledge on the aspects of interaction between production functions. The elicited knowledge was entered into FRAM Model Visualizer 0.4.1 software, which presents a graphical map of the system and allows the number of couplings $(N C)$ to be analyzed.

Findings - The analysis of the NCs highlighted that the laboratory control, burner, drum dryer, and baghouse functions showed a high potential for variability absorption, while the PLC control system and laboratory control functions have a high potential for fault propagation. Both groups were examined and measured explored within the scope of resilience engineering that enhance their roles in mitigating resilience within the system.

Originality/value - The replication of the resilience engineering discussed in this article enables gains in productivity and quality in sociotechnical systems for the same segment; the application of the functional resonance analysis methodology demonstrated can benefit further studies on productive systems with interaction between people and technology.

Keywords - Resilience engineering, productive systems, sociotechnical systems, FRAM.

11.Rua Norberto Domenico Schmatz 121, Bloco B 602, Moinhos, Lajeado - RS, CEP 95900-894, fvolken@universo.univates.br, https://orcid.org/0000-0002-9572-7610; $2 . \quad$ claudio.rosario@univates.br; https://orcid.org/0000-0002-7548-3380.

VOLKEN, F.G.B.; ROSÁRIO, C.R. The use of resilience engineering tools for fault propagation mitigation in sociotechnical systems. GEPROS. Gestão da Produção, Operações e Sistemas, v.16, no 2, p. 39 - 73, 2021.

DOI: http://dx.doi.org/10.15675/gepros.v16i2.2720 


\section{INTRODUCTION}

The phenomenon of variability in the production process is the object of study both from the point of view of quality in production and from the point of view of safety in manufacturing systems. While from the point of view of quality, variability generates inadequacy to use (JURAN, 2011) and losses to society (TAGUCHI, 1986), for safety in production systems, it impacts on the increased probability of failures and accidents (DEKKER, 2003).

Variability in processes is a characteristic present in socio-technical systems (STS's), which are composed of people and technology, also presenting high complexity due to the interaction between its components, which are submitted to human, technological and organizational factors (WOO; VICENTE, 2003). For Dekker (2011), human factors comprise the performance of people, who perform functions within this system, generally presenting great variability in their performance, given their physical and psychological conditions. The technological factors include both machinery and equipment, as well as operating procedures. These factors tend to present a smaller spectrum of variability, however, the failures presented tend to have more severe impacts, such as traffic accidents due to mechanical wear of components. Portela (2016) and Wachs (2016) complement the composition of the STS's, adding the organizational aspect, referring to work organization, centralization and formalization of activities and hierarchy relations; and the external environment, considering the socioeconomic, educational, political, cultural and legal issues. Organizational aspects have the potential to increase or decrease variability impacts, and this can be observed in situations where the organization imposes to the operation goals that are conflicting, such as charging more productivity, with lower cost and greater protocol safety, without correctly defining to what extent the costs related to the increase in productivity and protocol safety are feasible. Additionally, there is the non-linearity characteristic of STS's, in which one variable is impacted by $\mathrm{n}$ other variables, and this in turn is also projected to many others, creating a complex network where no event is easily explained by an isolated cause; for this reason, isn't rare the literature uses the definition of complex socio-technical systems.

Fogaça (2015) argues that the complexity of a system is linked to the number of variables and their interactions. The interactions can be linear, causing sequences of predictable events, or non-linear, making these systems unpredictable and increasing the 
complexity of control. Rassmussen (1997), Leveson (2004) and Hollnagel et al. (2014) point to the inherent difficulty of the human being in dealing with complexity, mainly in systems involving several variables, which lowers the reliability of the system. Thus, Dekker (2011) claims that the different manifestations of variability, such as poorly made instructions, inaccurate data or unexpected conditions, force the system to promote adaptations, whether by shortening activities or breaking protocols. When these adaptations of the work cannot absorb the variation on the input side, unsatisfactory outputs can be generated, such as results that will not satisfy the preconditions of subsequent processes, pressing the variability beyond the expected limits. Hollnagel et al. (2008) characterize this condition as emerging failure; a near failure in one process can generate minor failures in subsequent processes, and these minor failures can generate major failures, causing serious accidents and/or system collapse. Because of large number of variables, and thus different and successive interactions, human, technological or organizational, an unexpected variation in the input of a process can propagate exponentially through the system; this is the phenomenon of failure propagation. Aiming at the identification and management of risks, resilience engineering is the answer to deal with the phenomena of variability and its impacts (RIGHI; SAURIN, 2011).

According to Hosseini et al. (2016), resilience is the ability to absorb impacts and return to initial condition. Resilience engineering is the science that studies how to develop this capacity in systems, gaining even more importance when it comes to socio-technical systems, where complexity and high human involvement make variability a great risk to failures and accidents, causing in waste of resources and worse, lives. Alvarenga et al. (2014) cite several tools for benchmarking and implementation of resilience engineering. For sociotechnical systems, the Functional Resonance Analysis Method (FRAM) is listed as an effective tool in identifying and understanding the main causes of failure propagation.

Alvarenga et al. (2014) describe FRAM as a mechanism of systemic analysis, which allows studies based on the variability of variable relationships in socio-technical systems, calling them functions. It is based on the premise that it is possible to enable applications of resilience engineering with the identification of functions with homeostatic and fault propagation potential. However, Wachs (2016) reports that studies on FRAM methodology are still in theoretical spheres, especially in field studies in Brazil, lacking practical cases of application of the model and allowing them to be reproduced for other studies. Thus, this 
article aims to demonstrate the use of FRAM as a tool of resilience engineering, allowing the reproduction of the model and improvement of studies in this sphere of knowledge.

\section{THEORETICAL FOUNDATION}

The application of resilience engineering involves the identification of stages in the process (here called functions) within the productive system, which have homeostatic potential. This potential, Hollnagel et al. argue (2014), means the capacity of the function to receive inputs with unexpected variabilities, and given its resilience capacity, prevent deviations from spreading through the process. These functions play an important role in productive systems, as they increase robustness and reliability in terms of performance, stabilizing the process. There are also functions that have high potential for failure propagation, which are functions whose outputs are used by a large number of subsequent functions, and as a small deviation is installed, there is a greater risk of this deviation being propagated during the process (DEKKER, 2011).

Resilience engineering (ER) is based on fundamental aspects, such as: a) monitoring behavior patterns and their variations during the operation of productive processes; b) anticipating risks and events, acting proactively; c) responding to variations effectively and aiming at the robustness of the system; and d) learning from facts experienced, both in success and failure (RIGHI; SAURIN, 2011).

Righi and Saurin (2011) state that one way to provide safer and more stable production systems for organizations dealing with complex systems composed of large numbers of variables is to develop the capabilities to detect risks to deal with system variability and uncertainty.

This perspective introduces the concept of Leveson (2006) for resilience, being the system skill to prevent or adapt to circumstances that generate instabilities, aiming to maintain control over the system desired performance. Dekker (2011) defines the resilient system as one that can adjust its functioning before during and after the occurrence of disturbances or variations. Initially approached by researchers of labor safety, for the purpose of understanding and designing systems that can deal with variabilities in order to isolate or cushion them so as not to be reflected in failures or accidents, studies conducted in the resilience engineering area branch out into its applicability to various systems, both under productive bias and in services, such as, for example, in the area of hospital and health care 
(healthcare industry), aviation and means of transport (rail, maritime and road), chemical and construction industries (RIGHI; SAURIN, 2011).

Resilience engineering seeks to understand how people deal with complexity and variability in systems, especially when subjected to pressure situations and often conflicting goals. It also evokes the idea that successes and faults are the result of variability in the performance of system components. This perspective should be approached through the understanding of how these components relate to each other, and how this relationship can impact on deviations, faults and accidents.

Vargas and Guimarães (2006) reinforce the importance that resilience engineering should not only explain the events that lead a system to failure, but also learn from the near failures that the impacts of variability cause in the system. Thus, it is a matter that ultimately seeks to predict and prepare actions for the possibilities of faults in the future.

Hollnagel et al. (2008) advocate that the application of resilience engineering should observe the maintenance of four fundamental aspects, which are:

a) Know what to look for (monitor patterns of behavior and their variations during the operation of the productive process, seeking to identify possible threats to stability);

b) Know what to expect (anticipate risks and events, acting proactively and correcting the course whenever necessary);

c) Know what to do (respond to variations effectively, seeking robust solutions taking into account the situation);

d) Understand what happened (learn the facts experienced, both in success and failure).

Complementary to the four aspects highlighted above, the application of resilience engineering involves the use of redundancy mechanisms, which, as they monitor the variables and their behavior, manage to anticipate deviations and respond in order to resume the stability of processes (PORTELA, 2016). Wachs (2016) relates some techniques that can be used to apply resilience in a productive system:

a) the use of information technologies in redundancy mechanisms, due to the ease in monitoring and presenting a large number of variables;

b) practices such as cross-checking of data, performed by professionals with different perspectives;

c) training of people involved in the fundamental aspects of resilience; 
d) use of comprehensive standard operating procedures, built to provide resources to respond to different situations, including the unexpected;

e) organizational support, such as the use of visual management of goals and workflows.

The concepts of resilience engineering are linked to another systemic spectrum that has gained importance in recent decades: the socio-technical systems (STS's). According to Dekker (2011), one of the objectives of resilience engineering is to assist in the safety, stability and productivity of STS's through the application of methodologies and tools that allow greater control over variability. Righi (2014) points out that, until the publication of her work, the studies involving the application of resilience engineering in socio-technical systems were predominantly described; however, she defends the application of resilience engineering due to its ability to deal with the complexity and variability presented by STS's.

Socio-technical systems present as a basic characteristic the involvement and systemic relationship of two factors: human (sociological part) and equipment and techniques (technological part) (DEKKER, 2011). The human factors comprise the performance of people, who perform functions within this system, and use the technological spectrum to generate outputs. The technological spectrum include both machines and equipment, under a more materialistic aspect, as well as a technical-methodological aspect, that is, it is possible to consider methodological procedures as technological aspects. Wachs (2016) complements the STS's composition by adding the organizational aspect, referring to work organization, centralization and formalization of activities and hierarchy relations; and the external environment, considering the socioeconomic, educational, political, cultural and legal issues. It also highlights the non-linearity characteristic of STS's, which are often also determined by complex socio-technical systems. Fogaça (2015) mentions researches that began to direct their work in the areas of socio-technical systems in the 80's, focusing mainly on the performance variability presented by the system's functions after events of great worldwide repercussion, such as the incidents in the nuclear power plants of Three Mile Island and Chernobyl, the explosion of the space shuttle Challenger and the disaster of the chemical industry in Bhopal, India.

Almeida (2008) adds that STS's are composed of a large number of subsystems and components, and are constantly promoting self-corrections and undergoing adjustments, both by design (they were designed for this) and by nature (human performance in adjustments). 
Thus, Righi (2014) highlights that the human factor has been crucial in the performance of STS's, since they have the ability to understand the variabilities and adjust them to the process. The machines still lack greater capacity for recognition, interpretation and decision making to respond to divergences in flows. Although there are already self-regulatory mechanisms and servomechanisms with loop-control build in, their adjustment capacities are still small in relation to the variability potential that a system can present (WOO; VICENTE, 2003).

Despite the strategic function of human factors in STS's, Koskela (1992) points to the inherent difficulty of the human being in dealing with complexity, mainly in systems involving several variables, which generates a lower reliability of the system. Fogaça (2015) determines that the complexity of a system is linked to the number of variables and the way they interact. The interactions can be linear, causing sequences of predictable events, or nonlinear, making these systems more unpredictable and more complex to control.

Righi (2014) also highlights that when it comes to STS's, variability, besides being inevitable, can present a positive aspect. As the socio-technical system has elements of resilience, the appropriate treatment for variability can be transformed into greater flexibility in the outputs of the system. However, for a system to be capable of this, it is necessary to have full knowledge of the effects of variability on functions. This knowledge can be provoked through STS's studies.

Dekker (2011) cites the elimination of maneuver margins to meet variability in attempts to optimize systems can bring improvements in local productivity, but from a global point of view may not have the same effect. The reduction of maneuver margins may compromise mechanisms of resilience, damaging the stability of the system, and leading to what is called the phenomenon of failure propagation. In this phenomenon, minor failures, arising from variabilities to which the functions of the system could not respond, causing larger failures and crossing the processes and becoming a major problem.

The application of resilience engineering goes through the identification of stages in the process within the productive system, which have homeostatic potential. This potential, Hollnagel et al. argue (2014), means the capacity of the function to receive inputs with unexpected variabilities, and given its resilience capacity, prevent deviations from spreading in the process. These functions play an important role in productive systems, as they increase robustness and reliability in terms of performance, stabilizing the process. There are also 
functions that have high potential for fault propagation, which are functions whose outputs are used by a large number of subsequent functions, and as a small deviation is installed, there is a greater risk of this deviation being propagated during the process (DEKKER, 2011). Hosseini et al. (2016) point out FRAM as a methodology linked to resilience engineering capable of evaluating variability and robustness in productive systems.

FRAM is a method of analysis developed by researchers of occupational safety and human realibility analysis and verifies how activities influence each other retrospectively or prospectively (ALVARENGA et al. 2014). Almeida (2008) calls FRAM with a proposal of a systemic and non-linear approach for accident and failure analysis, taking into consideration two basic premises:

a) abandoning the perspective of causality in seeking linear explanations of failures or accidents;

b) adoption of the perspective of concepts of performance variability and local adaptations in the functions performed by system components.

Hollnagel et al. (2014) emphasize that FRAM tries to describe what happens with the functions involved in the process, explaining what is necessary for the result of the interactions to be positive and as expected. Four principles underlie the use of FRAM:

- Principle of equivalence - the perspective that both failures and successes are the result of interactions between functions, that is, they are constructed in the same way, through the relationships in the system. It is also based on the concepts of resilience engineering, where in a process which presents a failure, it may quickly recompose itself and present a positive result;

- Principle of approximate adjustments - understanding that people continuously end up adjusting their activities to meet the existing conditions of execution (considering resources, demands, opportunities, conflicts and interruptions) generating variability in performance and thus forming another reason for both positive and negative results;

- Principle of emergency - assumes that hardly the variability in just one function will be great enough to cause a failure or accident, but that combinations of variabilities in multiple functions may lead to disproportionate and non-linear consequences, making both failures and normal performances emergent results and not the fruits of a punctual event or phenomenon; 
- The principle of resonance - evoked when there are situations where it is not possible to explain a result by means of the principle of causality (cause-effect). Functional resonance occurs when the variability of a function is projected and influences the variability of other functions, and vice versa, causing non-linear and unexpected results.

The method of functional resonance analysis has some prerogatives that contribute to its objective of explaining the normal performance of a system (success) as well as the occurrence of some fault as an emergent phenomenon (WOLTJER; HOLLNAGEL, 2008). These prerogatives deal with the functions that make up the system under analysis, characterizing them through six different aspects of interaction, to quote (ALMEIDA, 2008):

- Inputs (I): activity that starts the function. It can also be conceived as the matter, energy or information that are transformed by the function;

- Outputs $(\mathrm{O})$ : products or results generated by the function;

- Resources (R): equipment, tools and information (can also be understood as hardware, software and manuals) used or consumed by the function in the execution of the activity;

- Controls (C): supervision systems, measurement of indicators and work organization methods that allow restricting and adjusting the function, when necessary;

- Preconditions (P): previous conditions or of the function itself, which are prerequisites and need to be complete before the execution of this function for a correct performance;

- Time (T): chronological unit of measurement that can be a critical factor in the performance of the function.

The aspects are organized in two groups, which can be upstream or downstream. The first group is composed by inputs, resources, controls, preconditions and time. These are aspects that receive interactions of other functions and/or variables, using them to perform their process. The greater the number of upstream aspects, the greater the homeostatic potential of the function, because there are more variables to subsidize decision making. The downstream group is made up of the outputs, are aspects where the function has played its role in the process, delivering the workflow to an aspect of the next function. Downstream aspects give their functions potential for fault propagation, because the more downstream aspects a function has, the more functions will be impacted in case of some emerging failure in the process. 
In FRAM there is no function limit as well as aspect limit; the same function can have several aspects of different resources, linked to other functions. When modeling a system using FRAM, a complex network of functions is formed, with connections that are not always obvious, and allow visualizing how each step of the process depends on a series of aspects.

\section{METHODOLOGICAL PROCEDURES}

FRAM is a recent approach and has been applied in socio-technical systems with a high degree of adaptation due to variability (FOGAÇA, 2015), both under the accident risk assessment bias and for the application of resilience to maintain process stability. Housseini (2016) and Righi (2014) cited the use of FRAM methodology allows a dynamic and systemic understanding of the factors that contribute to the results, expected or not. FRAM is a method that allows mapping the variables of a process and their interactions, calling them functions. The analysis of functions allows identifying what are the greatest impacts on the variability of the process, providing subsidies so that measures can be taken to increase the resilience and therefore the stability of the productive system. Figure 1 presents a diagram about the application of FRAM.

Figure 1 - FRAM applications

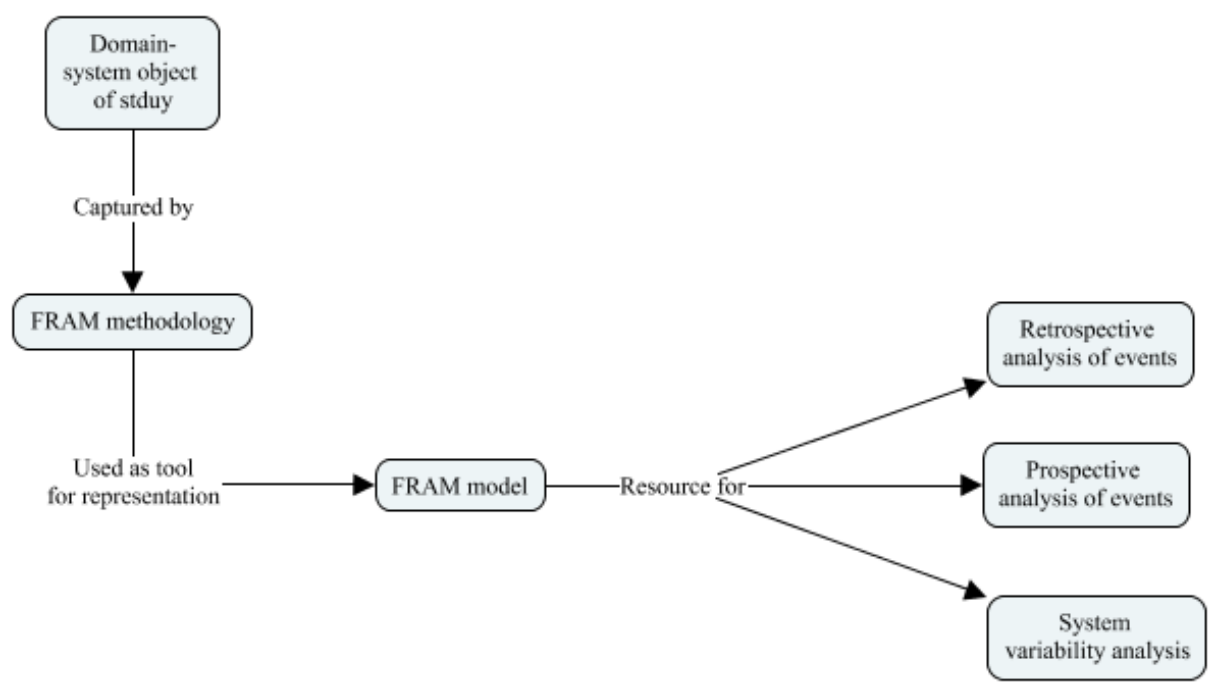

Source: adapted from Hollnagel (2012).

For the application of this methodology, a hot mix asphalt concrete plant (HMA) was chosen, located in an industrial cluster in the interior of Rio Grande do Sul, which meets the 
demands of the road works sector of a civil construction company. This productive system was chosen to mix human and technological variables, given that the civil construction segment has historically lagged in terms of safety, quality and productivity in relation to manufacturing industries (KOSKELA, 1992).

The production process of HMA, popularly known as 'asphalt', is sensitive to large number of variables, starting with the demand for its product, which oscillates to the detriment of the progress of asphalt paving road works. As the consumption of the HMA of these works depends on the favorable climate, release of inspectors and previous stages completed, adding the fact the HMA is a product that can not be stored under penalty of being out of specification due to loss of temperature and disintegration of the material, the production schedule becomes very dependent on the pace of application of the work, which can impact losses in productivity and increased fuel consumption in the process. This consumption also depends directly on the volume of HMA to be produced on the day, because an increase in fuel use efficiency is achieved through intermittent production. The volume of the main stocked raw material, the petroleum asphalt cement (AC), also influences the storage costs, because the greater the amount stored, the more energy is demanded in its heating, in addition to the fact that larger tanks need larger and more robust storage basins. The replenishment of this material also requires precise logistics, since it has large minimum lot units in relation to the tanking capacity, but they can become small in relation to the production volume demanded by a certain work in one day. The aggregates (composition of crushed materials) used in the HMA need to present granulometry and moisture indexes within the project of inspection agencies, otherwise it will be necessary the use of other material (for granulometric ranges out of specification) or greater the consumption of fuel for heating and drying.

Added to these facts, there is also a lack of work and research in this sector improving the flows of production processes. Operation training and good practices end up under the tutelage of equipment manufacturers and companies that have the resources to pay for them. Thus, this industry can be verified that presents a tendency to a great variability influencing the system. Obtaining a continuous and uninterrupted production process, using fuels efficiently and safely, but without compromising quality, productivity and the environment, are challenges to be faced day-after-day. 
After choosing the system that will be the object of study, the FRAM methodology is used to elicit knowledge and perform a mapping of process variables, which are represented in the graphic model as functions, which connect among themselves through six different types of aspects. With this model it becomes feasible retrospective analysis of events, such as accidents at work; prospective analysis of events, as a basis for studies of risks and possible failures; and finally, analysis of variability in systems, to propose tools and resources for their management, both in existing systems and for the design of new systems.

Hollnagel et al. (2014) reinforce the importance and propose that the elicitation of knowledge be carried out as the basis of interviews with expert system personnel. Bibliography reading can also be used, but given the phenomenon of adaptation of work, written procedures are not always respected in practice by the actors of the system. The proposal is that the interview be carried out in loco, where the operation is carried out. The questions to be asked should focus on daily routines, instead of specific successes and failures. Table 1 shows the questions proposed by Hollnagel et al. (2014) for the elicitation of the knowledge needed for the methodology.

Table 1 - Possible questions for applying the FRAM methodology

\begin{tabular}{|l|}
\hline When do you start this activity? What are the "signs" for the beginning? \\
\hline $\begin{array}{l}\text { How do you adjust the activity to different conditions? How do you } \\
\text { determine how and when to make adjustments? }\end{array}$ \\
\hline How often do you change or adjust the performance of your tasks? \\
\hline $\begin{array}{l}\text { How do you respond if something unexpected happens? For example, an } \\
\text { interruption, or a pause to fulfill another urgent demand, or the lack of } \\
\text { some resource? }\end{array}$ \\
\hline $\begin{array}{l}\text { How stable is the work team? Is the team always the same, or is it } \\
\text { adjusted/allocated daily? What happens if the team is out of work? }\end{array}$ \\
\hline How stable is the environment, supplies, resources and demands? \\
\hline Are there any unwanted conditions you need to tolerate or get used to? \\
\hline What preconditions are usually met? \\
\hline What factors are taken for granted? \\
\hline $\begin{array}{l}\text { How do you prepare for your work? (documents, procedures, instructions, } \\
\text { colleagues, etc.) }\end{array}$ \\
\hline $\begin{array}{l}\text { What information do you need (equipment, services, etc.)? What do you do } \\
\text { if this information is not available? }\end{array}$ \\
\hline How much pressure for time affects your work? \\
\hline What skills do you need? Does everyone on the team who does this work \\
\hline
\end{tabular}




\begin{tabular}{|l|} 
have these skills? \\
\hline What is the optimal performance for this work (if any)? \\
\hline
\end{tabular}

Source: adapted from Hollnagel (2012).

To elicit knowledge and execute the systemic mapping, interviews were conducted with three specialists in the process, chosen by the criteria of professional activity time in the area (more than 15 years) and positions held, such as production manager, plant operator and laboratory professional (responsible for quality control). The model for the interview script, which can be consulted in Appendix A, was based on the scripts used by Fogaça (2015) and Wachs (2016) in the respective data collections for their FRAM models. The questions directed to the aspects of the functions are also included in the work of Hollnagel et al. (2014) as possible questions for elicitation of knowledge for mapping and functional resonance analysis. However, questions indicated in the script may have been added and/or adapted during the interview, depending on the progress and interest of the interviewed participant. The objective of this proposed interview model is to make the interviewee narrate his or her routine, telling him or her what signs or preconditions show him or her that they should start a new activity, what resources are necessary for the correct performance, if there are other factors that should be taken into consideration during the activity and what should be delivered so that the next activity is also well performed. Thus, the interviewee describes all the functions existing in his mental model of the process, including the interactions of the functions among themselves, which must be characterized by the interviewer among the six aspects of FRAM (input, output, resources, controls, preconditions and time).

The material collected in the interviews - as well as their interaction aspects - was released directly in the FRAM model visualizer software - version 0.4.1. As the functions are fed and the aspects filled in, the program links the downstream aspects (outputs) of a function to the upstream aspects (inputs, resources, controls, preconditions and time) of the following functions, whenever the expression is exactly written the same way. The software recognizes the interactions between two or more functions, representing the production process under non-linear systemic bias. A function may also have an aspect that is not directly linked to another function; in this case, the software shows the aspect circulated in red.

The software also provides a report where all the functions inserted in the program are listed, as well as the description of each of the aspects assigned to them. Based on this report, 
it is possible to count the number of aspects (NAC's) upstream and downstream of each function. The purpose of counting this data is to verify the representativeness of the number of NACs of each function, within the total of observed NACs, and then to show which are the functions most impacted by the variability phenomenon (HOLLNAGEL et al. 2014). Wachs (2016) mentions that functions with homeostatic potential are those with high NAC's, that is, precisely because they receive large number of variables, they can monitor the behavior of patterns and anticipate actions to avoid unwanted events. Functions that interact with large number of functions in their output, on the other hand, have the potential to propagate failures, because unanticipated variations in their results can impact emerging failures in subsequent functions.

For the most representative functions of the system, action plans are drawn up, called maneuver margins, which allow the actors of the system to make adaptations in the work to contain the propagation of failures. However, the methodology does not foresee a cut-off point to select the most expressive functions in the system. Thus, after the interviews and modeling of the system, the authors defined a cutoff point based on the amount of functions mapped, so that a deeper analysis could be done in a few functions, but that represented a large part of the variability potential of the system.

\section{RESULTS}

The applied interviews occurred successively, and although the script and approach are the same, the answers vary according to the mental models of each interviewee, complementing holistically the modeling of the system, and presenting variables that are not in manuals, but treated in daily life by the professionals involved. As for the conduction of the interviews, they started with the registration of the name, position and function time of each professional, requesting that the production process of the HMA in a routine journey be described. As the productive functions were described, the questions of functional mapping were used, requesting each interviewee to return to the aspects that compose each function. Allied to the interviews, field observation was performed during the plant operation, totaling 16 hours of follow-up, four periods of 4 hours each. The field observation is important because it verifies in loco the information obtained in the interviews, besides helping the 
researcher to better understand the productive process and the challenges faced by those who need to conduct the operation meeting conflicting goals.

After conducting the interviews and field observation, the FRAM Model Visualiser software - version 0.4.1 was used to insert the data. The use of this software facilitates the characterization of the function aspects, because for each function inserted in the model, the software presents fields so that the aspects are described.

\subsection{FRAM Graphic modeling}

As functions are inserted, and their aspects described, interactions are established. These interactions are represented by a line connecting the aspects, following the following rule: the expression that is contained downstream, that is, in the output aspect of a function, must be exactly the same as the expression contained in any of the aspects upstream of another function. A network is formed where it is possible to visualize how the system and its components relate, as well as the paths through which faults may propagate. It was also chosen to adopt visual identification through colors, presenting functions linked to cost aspects such as red, quality identified with blue, environment with green, and security with yellow. The graphic modeling is presented in Figure 2.

Figure 2 - FRAM Model output for HMA production process

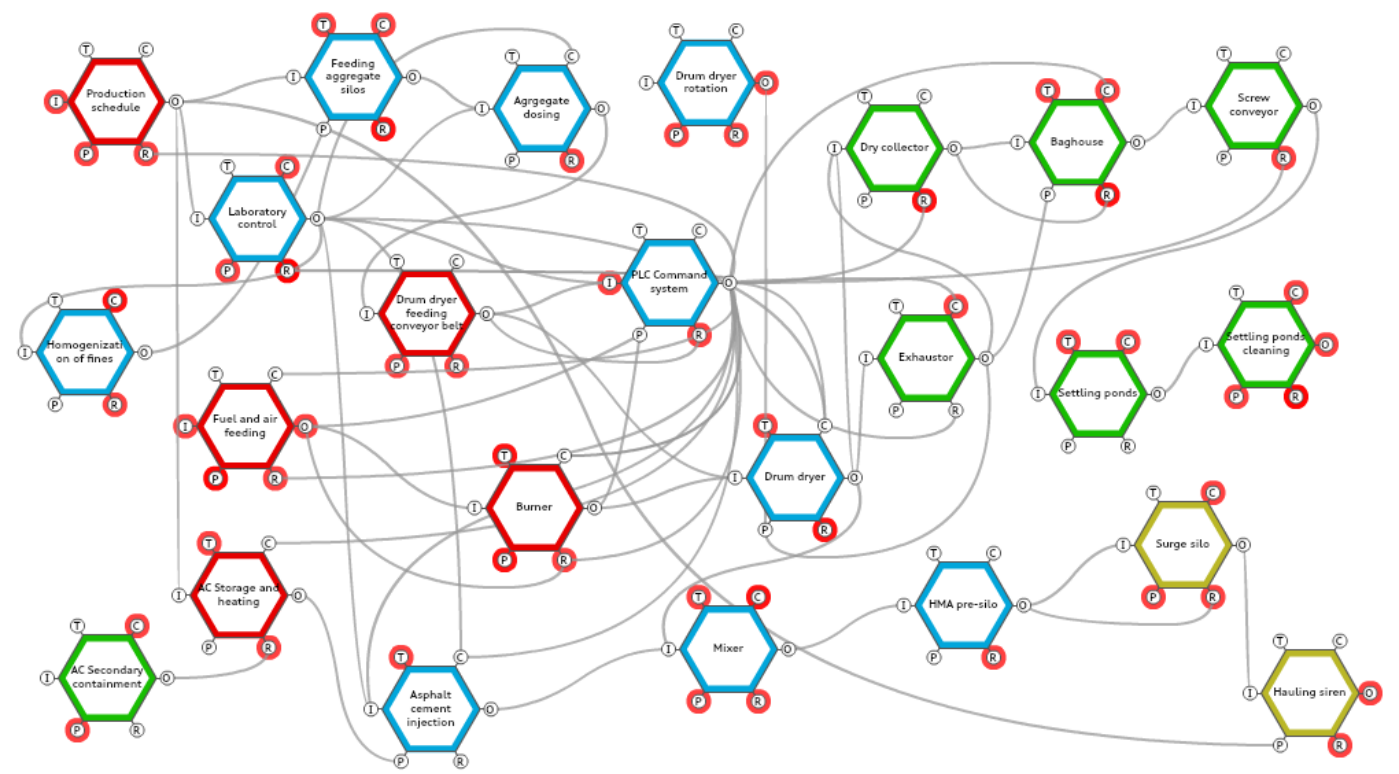

Source: The authors (2018). Produced with the FRAM Model Visualiser - version 0.4.1. 


\subsection{Analysis of the number of aspects}

Based on the mapping of the functions in the previous section, the analysis of the number of aspects can be performed. For this purpose, all the aspects upstream and downstream of each function are added together. Functions that receive more NAC's upstream have a greater diversity in input and information, making their performance more complex. This complexity is taken as one of the reasons of the unexpected variabilities generated; however, according to Righi (2014), these are functions that have high suitability for resilience tools, damping the variabilities and standardizing their results. On the other hand, functions with higher NAC's downstream, have greater impact on the system stability, because if there is some failure in its performance, there will be the propagation to a greater number of functions.

Table 2 presents the analysis of the number of aspects of the mapped functions. The functions totaled $130 \mathrm{NAC}$ 's upstream, and 49 NAC's downstream, totaling 179 mapped specs.

Table 2 - Number of aspects per function.

\begin{tabular}{l|c|c}
\multicolumn{1}{c}{ FUNCTION } & \multicolumn{2}{c}{ NUMBER OF COUPLINGS } \\
\cline { 2 - 3 } & UPSTREAM & DOWNSTREAM \\
\hline FEEDING AGGREGATE SILOS & 6 & 1 \\
\hline HOMOGENIZATION OF FINES & 4 & 1 \\
\hline AGGREGATE DOSING & 4 & 1 \\
\hline DRUM DRYER FEEDING CONVEYOR BELT & 3 & 2 \\
\hline DRUM DRYER & 9 & 2 \\
\hline BURNER & 7 & 2 \\
\hline FUEL AND AIR FEEDING & 2 & 3 \\
\hline DRY DRUM ROTATION & 6 & 1 \\
\hline ASPHALT CEMENT INJECTION & 7 & 1 \\
\hline MIXER & 2 & 1 \\
\hline HMA PRE-SILO & 5 & 1 \\
\hline SURGE SILO & 3 & 1 \\
\hline HAULING SIREN & 4 & 1 \\
\hline EXHAUSTOR & 5 & 1 \\
\hline AC STORAGE AND HEATING & 2 & 1 \\
\hline AC SECONDARY CONTAINMENT & 8 & 1 \\
\hline BAGHOUSE & 3 & 5 \\
\hline SCREW CONVEYOR & 3 & 3 \\
\hline SETTLING PONDS & 16 & 1 \\
\hline LABORATORY CONTROL & 5 & 1 \\
\hline DRY COLLECTOR & 2 & 1 \\
\hline
\end{tabular}




\begin{tabular}{l|c|c} 
PLC COMMAND SYSTEM & 6 & 11 \\
\hline PRODUCTION SCHEDULE & 4 & 4 \\
\hline SETTLING PONDS CLEANING & 6 & 1 \\
\hline TOTAL & 130 & 49
\end{tabular}

Source: The authors (2018). The order in which the functions appear follows the same order as the function report automatically generated by the FRAM Model Visualiser - version 0.4.1.

In the following two sections, the NAC's upstream and downstream will be analyzed in each one. As tools for the analysis and obtaining of the most important functions in the system, the representativity of each function within the system will be weighted, adopting a cut-off point of $33 \%$ of the number of accumulated NACs. From obtaining the most impacting functions, it is verified, with the help of the software, how the variability can be presented.

\subsubsection{Upstream NAC's analysis.}

Based on the FRAM methodology, the upstream NAC's represent the aspects that feed the functions, being them: input, time, control, resources and preconditions. These aspects condition the practical performance of each function, each of which can be a different source of variability. Functions that have large number of NAC's are important for complex systems, because they can be used to absorb eventual failures in previous functions, increasing the levels of resilience in the productive processes. Table 3 shows how the functions are organized according to the number of upstream NACs, in descending order. It is possible to verify in the 'representativity' column how representative the function is, according to its number of upstream NACs, in relation to the total.

Table 3 - Upstream NAC's

\begin{tabular}{l|c|c|c}
\multicolumn{1}{c|}{ FUNCTIONS } & $\begin{array}{c}\text { UPSTREAM } \\
\text { NCs }\end{array}$ & REPRESENTATIVITY & $\begin{array}{c}\text { REP. } \\
\text { ACCUMULATED }\end{array}$ \\
\hline LABORATORY CONTROL & 16 & $12 \%$ & $12 \%$ \\
\hline BURNER & 10 & $8 \%$ & $20 \%$ \\
\hline DRUM DRYER & 9 & $7 \%$ & $27 \%$ \\
\hline BAGHOUSE & 8 & $6 \%$ & $33 \%$ \\
\hline FUEL AND AIR FEEDING & 7 & $5 \%$ & $38 \%$ \\
\hline MIXER & 7 & $5 \%$ & $44 \%$ \\
\hline FEEDING AGGREGATE SILOS & 6 & $5 \%$ & $53 \%$ \\
\hline ASPHALT CEMENT INJECTION & 6 & $5 \%$ & $58 \%$ \\
\hline PLC COMMAND SYSTEM & 6 & $5 \%$ & $62 \%$
\end{tabular}




\begin{tabular}{l|c|c|c} 
SURGE SILO & 5 & $4 \%$ & $66 \%$ \\
\hline AC STORAGE AND HEATING & 5 & $4 \%$ & $70 \%$ \\
\hline DRY COLLECTOR & 5 & $4 \%$ & $74 \%$ \\
\hline HOMOGENIZATION OF FINES & 4 & $3 \%$ & $77 \%$ \\
\hline AGREGGATE DOSING & 4 & $3 \%$ & $80 \%$ \\
\hline EXHAUSTOR & 4 & $3 \%$ & $83 \%$ \\
\hline PRODUCTION SCHEDULE & 4 & $3 \%$ & $86 \%$ \\
\hline DRUM DRYER FEEDING & 3 & $2 \%$ & $88 \%$ \\
CONVEYOR BELT & 3 & $2 \%$ & $91 \%$ \\
\hline HAULING SIREN & 3 & $2 \%$ & $93 \%$ \\
\hline SCREW CONVEYOR & 3 & $2 \%$ & $95 \%$ \\
\hline SETTLING PONDS & 2 & $2 \%$ & $97 \%$ \\
\hline DRY DRUM ROTATION & 2 & $2 \%$ & $100 \%$ \\
\hline HMA PRE-SILO & 2 & $2 \%$ & \\
\hline AC SECONDARY & & $100 \%$ & \\
\hline TONTAINMENT & 130 & & \\
\hline SOUT: THA & & & \\
\hline
\end{tabular}

Source: The authors (2018).

\subsubsection{Maneuver margin projection for functions with homeostatic potential}

The laboratory control function (Figure 3) is responsible for assessing, through laboratory tests, the quality and conformity of raw materials and finished product, to the standard established in projects created by the inspection agencies (National Department of Infrastructure and Transportation - DNIT, Autonomous Department of Roads and Highways DAER, among others). For the correct performance of its function in the process, the laboratory tests can be understood as resources, because the results tested are processed as by the laboratory subsidizing the decision making. Based on these tests, interventions in production can be defined to adjust parameters and corrections of projects with deviations, even production interruption, for situations in which the raw material and/or its processing presents insufficient conditions of conformity to the project and application of the material.

Because most of the NAC's in this function have resource aspects, the improvement of the resilience in this function must be able to guarantee the isonomy in the work and efficacy of the tests. Wachs (2016) cites for these cases the resilience skills (RS), which should be trained to the professionals of the process, enabling the realization of margins of maneuver in the performance of their activities. Among the RS's stipulated by the cited author are the capabilities of collaborative work and intercommunication, management, recognition of the impact of decisions and changes in variables, identification of contextual factors that can 
impair performance, anticipation of the need for actions, alternative solutions involving the use of equipment and materials and leadership.

Figure 3 - Laboratory control function

\begin{tabular}{|c|c|}
\hline Name of function & Laboratory control \\
\hline Description & $\begin{array}{l}\text { The laboratory control function is responsible for assessing, through laboratory } \\
\text { tests, the quality and conformity of raw materials and finished product, to the } \\
\text { standard established in projects created by the inspection agencies (National } \\
\text { Department of Infrastructure and Transportation - DNIT, Autonomous Department } \\
\text { of Roads and Highways - DAER, among others). }\end{array}$ \\
\hline Aspect & Description of Aspect \\
\hline Input & $\begin{array}{l}\text { Evaluation of available materials seeking to ensure the HMA project } \\
\text { requirements. }\end{array}$ \\
\hline \multirow[t]{5}{*}{ Output } & Laboratory determines the RPM of the dosing belts \\
\hline & Moisture control on the aggregates available for machining \\
\hline & $\begin{array}{l}\text { Laboratory uses moisture content to regulate the feeding conveyor productivity to } \\
\text { the drum dryer }\end{array}$ \\
\hline & $\begin{array}{l}\text { Laboratory regulates the } \mathrm{AC} \text { injection based on the rotarex content test, which } \\
\text { must fit the project content of the mixture }\end{array}$ \\
\hline & Control of the aggregates moisture at the drum dryer outlet: below $0.5 \%$ of mass \\
\hline Precondition & Qualified laboratory employee, technical knowledge \\
\hline \multirow[t]{13}{*}{ Resource } & Equipment (laboratory available) \\
\hline & $\begin{array}{l}\text { Rotarex content (test to measure asphalt cement content). The content may vary } \\
\text { a maximum of } 0.3 \text { percentage points above or below the optimal content }\end{array}$ \\
\hline & Moisture content of aggregates available for machining \\
\hline & Material granulometry test \\
\hline & $\begin{array}{l}\text { Aggregates temperature control at the drum dryer outlet: optimum range between } \\
150^{\circ} \mathrm{C} \text { and } 155^{\circ} \mathrm{C}\end{array}$ \\
\hline & HMA temperature control in the mixer: optimum range from $160^{\circ} \mathrm{C}$ to $165^{\circ} \mathrm{C}$ \\
\hline & $\begin{array}{l}\text { Aggregate health test - evaluates the resistance of the aggregate to } \\
\text { disintegration by the action of time. The result should present a loss of less than } \\
12 \% \text { for large aggregate, and } 15 \% \text { for fine aggregate (DNER-ME 089). }\end{array}$ \\
\hline & $\begin{array}{l}\text { Los Angeles abrasion test - evaluates the resistance of aggregates to wear due } \\
\text { to mechanical friction. The test result must be equal to or less than } 40 \% \text { (DNER- } \\
\text { ME 086) }\end{array}$ \\
\hline & $\begin{array}{l}\text { Water absorption test - measures the capacity of the large aggregate to retain } \\
\text { water in its pores }\end{array}$ \\
\hline & $\begin{array}{l}\text { Lamellarity index test - related to the aggregate shape. The more cubic the } \\
\text { material, the greater the shear strength and the harder it will break during rolling. } \\
\text { Index of form higher than } 0.5 \% \text { (DNER-ME 086). }\end{array}$ \\
\hline & $\begin{array}{l}\text { Adhesion test - determines the ability of the asphalt cement to coat to the } \\
\text { aggregates }\end{array}$ \\
\hline & $\begin{array}{l}\text { Sand equivalence test - determines the quality of the material, relating the quality } \\
\text { of granular material to the amount of clay or impurities. The small aggregate } \\
\text { should present sand coefficient equal or superior to } 55 \% \text { (DNER-ME 054) }\end{array}$ \\
\hline & $\begin{array}{l}\text { Marshall test - determines in an emirical way how much of resistance to the } \\
\text { average traffic the compacted asphalt mass will present. For a pressure of } 500 \mathrm{~kg} \\
\text { in the test body, it should present fluidity of less than 0.01" (DNER 043/94) }\end{array}$ \\
\hline Control & Technical standards (NBR, DNIT, DAER, etc.) \\
\hline Time & \\
\hline
\end{tabular}

Source: The authors (2018). Produced with the FRAM Model Visualiser - version 0.4.1.

The RS's projections for laboratory activities are described in Table 4. The column "Fundamentals of RE" relates the RS to the four conceptual pillars of resilience engineering. 
In the "Practices" column, it is possible to verify examples of RS practices, thus contributing to the cushioning of eventual variability in the aspects of input, time, control, resources and pre-conditions of the laboratory control function.

Table 4 - Resilience skills application

\begin{tabular}{|c|c|c|}
\hline Fundamentals of RE & Resilience skills & Practical \\
\hline Monitor & $\begin{array}{l}\text { Identification of contextual } \\
\text { factors }\end{array}$ & $\begin{array}{l}\text { Perform periodic laboratory tests according to } \\
\text { production; } \\
\text { Carry out extra laboratory tests whenever there is } \\
\text { evidence of changes in in the context of the } \\
\text { production system; }\end{array}$ \\
\hline Anticipate & $\begin{array}{l}\text { Collaborative work and } \\
\text { intercommunication; } \\
\text { Identification of contextual } \\
\text { factores; } \\
\text { Leadership; }\end{array}$ & $\begin{array}{l}\text { Verify climatic conditions; } \\
\text { Follow the aggregates mining front; } \\
\text { Receive deliveries of asphalt binders and fuels, } \\
\text { analyzing the quality certificate; } \\
\text { Aligning demands with the loader operator; }\end{array}$ \\
\hline Respond & $\begin{array}{l}\text { Recognition of the impact of } \\
\text { decisions and changes in } \\
\text { variables; } \\
\text { Alternative solutions involving } \\
\text { the use of equipment and } \\
\text { materials; } \\
\text { Leadership; }\end{array}$ & $\begin{array}{l}\text { Requesting interventions in production variables, to } \\
\text { ensure the quality of the material produced; } \\
\text { Set new RPM to feed belt compositions matching } \\
\text { asphalt binder injection, aiming to comply with the } \\
\text { project specifications; } \\
\text { Propose the use of other types of materials, when the } \\
\text { complementation of the granulometry is necessary; }\end{array}$ \\
\hline Learn & To register the lessons learned; & $\begin{array}{l}\text { To register in a logbook and/or database system the } \\
\text { interventions performed } n \text { the operation, as well as } \\
\text { the result of the resulting laboratory tests. }\end{array}$ \\
\hline
\end{tabular}

Source: The authors (2018).

The practices of resilience skills should be known and used as a goal in training of the professionals involved in the process.

The function of the burner (Figure 4) is to burn fuel and air, to generate the necessary heat for drying and increasing the temperature of the aggregates, inside the dryer. Its performance is largely linked to aspects that configure the calibration and feeding of the inputs that will be burned, as well as the regulation of the flame power. Variations in these aspects can lead to an ineffective flame, not satisfying the output objectives of the function. 
These variations can occur due to climatic conditions, such as ambient temperature, changes in the density and, therefore, the fuel supply pressure, as well as failure in some component in the supply system.

Figure 4 - Burner funcion

\begin{tabular}{|l|l|}
\hline Name of function & Burner \\
\hline \multirow{2}{*}{ Aspecription } & $\begin{array}{l}\text { It provides, through the burning of fuel and oxidizer, the necessary heat for } \\
\text { drying. }\end{array}$ \\
\hline \multirow{2}{*}{ Input } & Description of Aspect \\
\hline \multirow{2}{*}{ Precondition } & Fuel and air system feeding \\
\hline \multirow{2}{*}{ Resource } & $\begin{array}{l}\text { With the combustion process, we have the flame that will dry the aggregates and } \\
\text { raise the temperature to } 160 \text { to } 170^{\circ} \mathrm{C}\end{array}$ \\
\cline { 2 - 3 } & Power supply via sensors \\
\hline & Burner calibration \\
\cline { 2 - 3 } & Manufacture according to ABNT NBR $12.313: 2000$ \\
\hline & Burner flame power regulation \\
\cline { 2 - 3 } & Fuel and air system feeding \\
\cline { 2 - 3 } & Shut-off valves close the gas and air inlet in case of out of specification pressure \\
\hline Control & Pressure regulation $\left(\mathrm{kgf} / \mathrm{cm}^{3}\right)$ of fuel supply and air \\
\cline { 2 - 3 } & Burner flame power regulation \\
\hline \multirow{2}{*}{ Time } & $\begin{array}{l}\text { The flame must start in } 3 \text { seconds, otherwise the burner is disarmed, displaying a } \\
\text { fault message }\end{array}$ \\
\cline { 2 - 3 } & Periodic preventive maintenance and regulation plan \\
\hline
\end{tabular}

Source: The authors (2018). Produced with the FRAM Model Visualiser - version 0.4.1.

To enable the plant operator to anticipate failures and variability in the process, a verification system with pressure gauges and control table, with acceptable minimum and maximum limits in each component will provide the operator with the ability to maneuver in order to regulate the feed properly to the context.

The drum dryer (Figure 5) is the compartment where the aggregates already dosed enter, receiving the flame from the burner, to decrease the moisture content and increase its temperature. Just receiving a powerful flame is no guarantee that the drying process will reach the desired parameters; on the contrary, the increase of the flame power can be a device used by the plant operator to hide failures in the drying process, such as a drum dryer with wornout shell fins, resulting in fuel waste. To reach the desired moisture and temperature parameters, the dryer needs to provide, through its rotation, a veil of falling aggregates, exposing them to the burner flames. This veil is provided by the internal flights in the drum length, which work by receiving the aggregates and carrying them in radial movement, until gravity forces the aggregates to fall, crossing the flame and reaching once again the flights in the lower position. 
Figure 5 - Drum dyer function

\begin{tabular}{|c|c|}
\hline Name of function & Drum dryer \\
\hline Description & $\begin{array}{l}\text { The aggregates pass through the dryer to be heated to } 160-170^{\circ} \mathrm{C} \text { and reduce } \\
\text { the moisture content to below } 0.5 \% \text { of weight. }\end{array}$ \\
\hline Aspect & Description of Aspect \\
\hline \multirow[t]{2}{*}{ Input } & Feeding in ton/hour in the drum dryer \\
\hline & $\begin{array}{l}\text { With the combustion process, we have the flame that will dry the aggregates and } \\
\text { raise the temperature to } 160 \text { to } 170^{\circ} \mathrm{C}\end{array}$ \\
\hline \multirow[t]{2}{*}{ Output } & The dry aggregates and the desired temperature are directed to the mixer \\
\hline & $\begin{array}{l}\text { As residues from the drying, there remain gases that have not been burned and } \\
\text { fine particles that should not go to the asphalt mixture }\end{array}$ \\
\hline \multirow[t]{2}{*}{ Precondition } & The rotation and inclination of the drum dryer lead the aggregates to the mixer \\
\hline & $\begin{array}{l}\text { Suction of the finest particles (passing at } \# 200 \text {, around } 5.0 \% \text { ) and gases from } \\
\text { incomplete burner burning (about } 1 \% \text { of fuel fed) through exhaustion }\end{array}$ \\
\hline \multirow[t]{2}{*}{ Resource } & $\begin{array}{l}\text { Flights along the drum lengh allow the shellding of the aggregates, in order to be } \\
\text { exposed them to the flame forming a veil }\end{array}$ \\
\hline & $\begin{array}{l}\text { Retaining ring retaining the aggregates inside the drum dryer, increasing drying } \\
\text { efficiency }\end{array}$ \\
\hline \multirow[t]{2}{*}{ Control } & $\begin{array}{l}\text { Aggregates temperature control at the drum dryer outlet: optimum range between } \\
150^{\circ} \mathrm{C} \text { and } 155^{\circ} \mathrm{C}\end{array}$ \\
\hline & Control of the aggregates moisture at the drum dryer outlet: below $0.5 \%$ of mass \\
\hline Time & $\begin{array}{l}\text { Drum rotation speed needs to meet the required productivity. The aggregate that } \\
\text { enters the dryer must be between } 90 \text { and } 150 \text { seconds, to then be directed to the } \\
\text { mixer }\end{array}$ \\
\hline
\end{tabular}

Source: The authors (2018). Produced with the FRAM Model Visualiser - version 0.4.1.

The drum's flights system suffers wear and tear over time, due to the abrasiveness and the shock performed by the aggregates at high temperature. Besides the flights system, a solution that is already applied to increase the resilience in the performance of the dryer, is the installation of internal retaining rings. These rings are nothing more than sheets welded perpendicularly along the internal circumference of the dryer. The purpose of these rings is to retain the aggregates for about one minute more in their passage through the dryer. The implementation of this solution dampens the variations in the NAC's upstream of the dryer function, because the longer time of the aggregates passage through the dryer allows soften the consumption of fuel and energy in the flames, as well as allowing feeding aggregates with higher than expected moisture levels, due to adverse weather conditions.

The Baghouse (Figure 6) works to retain the finest particles through fabric bag filters, usually made of material composed of Polyester, limiting the emission of particles up to 90 $\mathrm{mg} / \mathrm{m}^{3}$. The system works with the emission of compressed air jets to perform the bag filters cleaning, directing them to the snail (helical transporter). The pressure of the compressed air shots must be regulated in 100 PSI for correct cleaning of the bag filters without damaging them. The shot time must also obey a frequency of 1 trip every 13 seconds. The temperature 
variable of the gases that enter the bag filter must be respected; the gases must be above $120^{\circ} \mathrm{C}$, under penalty of condensation and sulfuric acid formulation, corroding the filters, and below $150^{\circ} \mathrm{C}$, otherwise, the high temperature of the gases can cause in the burning of the tissues, also leading to their degradation. As resources, the system counts with the dry collector, in which a gate can be opened to regulate the entrance of atmospheric air, reducing the speed and temperature of the gases in the baghouse.

Figure 6 - Baghouse function

\begin{tabular}{|l|l|}
\hline Name of function & Baghouse \\
\hline Description & $\begin{array}{l}\text { Retention of the particles through filters of tissue usually Polyester, limiting the } \\
\text { emission of particles up to } 90 \mathrm{mg} / \mathrm{m}^{3} \text {. The system foresees the emission of } \\
\text { compressed air jets to perform the filters cleaning, directing them to the snail } \\
\text { (helical transporter). Gas entries below } 120^{\circ} \mathrm{C} \text { can cause gases to condense to } \\
\text { sulfuric acid, corroding sleeve tissues; entries above } 150^{\circ} \mathrm{C} \text { can cause tissues to } \\
\text { burn, also leading to tissue degradation. }\end{array}$ \\
\hline \multirow{2}{*}{ Aspect } & Description of Aspect \\
\hline \multirow{2}{*}{ Output } & $\begin{array}{l}\text { Directing the lightest particles, as well as combustion residues, to the bag filter } \\
\text { system }\end{array}$ \\
\hline Precondition & $\begin{array}{l}\text { The bag filters retain the particles until they are triggered by the shot of } \\
\text { compressed air and directed through a funnel to the screw conveyor }\end{array}$ \\
\hline Resource & $\begin{array}{l}\text { Suction of the finest particles (passing at \#200, around } 5.0 \% \text { ) and gases from } \\
\text { incomplete burner burning (about } 1 \% \text { of fuel fed) through exhaustion }\end{array}$ \\
\hline & $\begin{array}{l}\text { The dry collector acts as a resource to soften the inlet temperature of the } \\
\text { particles in the bag filter, avoiding damage to them }\end{array}$ \\
\cline { 2 - 3 } & Compressed air system for cleaning the bag filters \\
\cline { 2 - 3 } & Resistance of materials used in the confection of bag filter fabrics \\
\hline Control & Temperature control in the bag filter: optimum range between $120{ }^{\circ} \mathrm{C}$ and $150{ }^{\circ} \mathrm{C}$ \\
\cline { 2 - 3 } & Compressed air pressure regulated at $100 \mathrm{PSI}$ \\
\hline Time & Time of compressed air jets shooting - every 13 seconds \\
\hline
\end{tabular}

Source: The authors (2018). Produced with the FRAM Model Visualiser - version 0.4.1.

For this function, aiming at the application of resilience in the process, it is based on the principle of anticipation of events. The input variables such as gas temperature, pressure and frequency of compressed air shots need to be monitored as specified, otherwise the bag filters tend to wear out prematurely and not fulfill their functions; the retention of the particles. Table 5 presents the variables, their specifications and the verification/regulation instrument that must be monitored by the plant operator.

Table 5 - Monitoring variables for the bag filter function 


\begin{tabular}{l|c|c|c} 
Compressed air display pressure & 100 PSI & Manometer & Air compressor \\
\hline Frequency of air disposal & 1 shot every $13 \mathrm{~s}$ & Sequencer & Sequencer \\
\hline Gas temperature & $>120^{\circ} \mathrm{C}$ to $<150^{\circ} \mathrm{C}$ & PT100 Sensor/ PLC & Cyclone
\end{tabular}

Source: The autores (2018).

The FRAM software allows the analysis of functions according to their characterization in human, technological or organizational aspects. In this work, of the four functions with homeostatic potential found, two present human factor and two technological factors of variability. Table 6 summarizes the scope of each function, as well as presents the notion of variability given by FRAM.

Table 6 - Variability analysis of upstream functions

\begin{tabular}{l|l|l|l} 
FUNCTION & POTENTIAL & FACTOR & \multicolumn{1}{|c}{ VARIABILITY ANALYSIS } \\
\hline $\begin{array}{l}\text { Laboratory } \\
\text { Control }\end{array}$ & Homeostatic & Human & $\begin{array}{l}\text { Highly connected to the resources of the asphalt lab } \\
\text { technician. In this function, the resources are the } \\
\text { laboratory tests performed, which allow the lab technician } \\
\text { to monitor patterns of behavior of the HMA inputs, } \\
\text { anticipating and acting whenever necessary. }\end{array}$ \\
\hline Burner & Homeostatic & Technological & $\begin{array}{l}\text { Large number of equipment regulation interactions, which } \\
\text { can prevent excessive costs in fuel consumption, as well as } \\
\text { safety valves regulation and periodic preventive } \\
\text { maintenance plan. }\end{array}$ \\
\hline Drum Dryer & Homeostatic & Technological & $\begin{array}{l}\text { The equipment may present variability related to wearing } \\
\text { out and lack of preventive maintenance, rotation with } \\
\text { unsatisfactory drum speed, excessive wear of fins and } \\
\text { retaining ring. The fins and retaining rings must be } \\
\text { replaced frequently, because they have strong homeostatic } \\
\text { potential damping input variations, such as the capacity to } \\
\text { deal with excessive humidity of the material entering the } \\
\text { process. }\end{array}$
\end{tabular}




\begin{tabular}{l|l|l} 
Baghouse & Homeostatic & $\begin{array}{l}\text { Variations in the fine material temperature entering the } \\
\text { function can damage the bag filters, causing their } \\
\text { deterioration - therefore attention to control functions, and } \\
\text { pressure calibration of the compressed jet for cleaning the } \\
\text { filters. }\end{array}$
\end{tabular}

Source: The authors (2018).

\subsubsection{Analysis of downstream NAC's}

Parallel to the analysis of upstream NACs, which make up the number of input variables and press the performance of functions, it is possible to analyze downstream NACs, which express the number of variables that will be impacted by the performance of these functions. The greater the number of NACs downstream, the greater the impact on the productive system, due to the propagation of functional failures. It is important to note that, according to the FRAM methodology literature (HOLLNAGEL et al. 2014), the performance of a function is expressed by its output,

and may vary in two instances: as to accuracy and as to time. Table 7 presents the table of analysis of downstream NAC's, organized in a decreasing way according to their representativeness.

Table 7 - Analysis of downstream NAC's

\begin{tabular}{l|c|c|c} 
FUNCTIONS & $\begin{array}{l}\text { DOWNSTREAMS } \\
\text { NECS }\end{array}$ & REPRESENTATIVITY & $\begin{array}{l}\text { REP. } \\
\text { ACCUMULATED }\end{array}$ \\
\hline $\begin{array}{l}\text { PLC COMMAND } \\
\text { SYSTEM }\end{array}$ & 11 & $22 \%$ & $22 \%$ \\
\hline $\begin{array}{l}\text { LABORATORY } \\
\text { CONTROL }\end{array}$ & 5 & $10 \%$ & $33 \%$ \\
\hline $\begin{array}{l}\text { PRODUCTION } \\
\text { SCHEDULE }\end{array}$ & 4 & $8 \%$ & $41 \%$ \\
\hline $\begin{array}{l}\text { FUEL AND AIR } \\
\text { FEEDING }\end{array}$ & 3 & $6 \%$ & $47 \%$ \\
\hline DRY COLLECTOR & 3 & $6 \%$ & $53 \%$ \\
\hline $\begin{array}{l}\text { DRUM DRYER FEEDING } \\
\text { CONVEYOR BELT }\end{array}$ & 2 & $4 \%$ & $57 \%$ \\
\hline DRUM DRYER & 2 & $4 \%$ & $65 \%$ \\
\hline BURNER & 2 & $4 \%$ & $69 \%$ \\
\hline DRY DRUM ROTATION & 2 & $4 \%$ & $71 \%$ \\
\hline $\begin{array}{l}\text { FEEDING AGGREGATE } \\
\text { SILOS }\end{array}$ & 1 & $2 \%$ & $73 \%$ \\
\hline HOMOGENIZATION OF & 1 & $2 \%$ & $76 \%$ \\
\hline FINES & 1 & $2 \%$ & $78 \%$ \\
\hline AGGREGATE DOSING & 1 & $2 \%$ & \\
\hline ASPHALT CEMENT & & & \\
\hline INJECTION & & & \\
\hline
\end{tabular}




\begin{tabular}{l|c|c|c} 
MIXER & 1 & $2 \%$ & $80 \%$ \\
\hline HMA PRE-SILO & 1 & $2 \%$ & $82 \%$ \\
\hline SURGE SILO & 1 & $2 \%$ & $84 \%$ \\
\hline HAULING SIREN & 1 & $2 \%$ & $86 \%$ \\
\hline EXHAUSTOR & 1 & $2 \%$ & $88 \%$ \\
\hline AC STORAGE AND & 1 & $2 \%$ & $90 \%$ \\
HEATING & 1 & $2 \%$ & $92 \%$ \\
\hline $\begin{array}{l}\text { AC SECONDARY } \\
\text { BANTAINMENT }\end{array}$ & 1 & $2 \%$ & $96 \%$ \\
\hline SCREW CONVEYOR & 1 & $2 \%$ & $98 \%$ \\
\hline SETTLING PONDS & 1 & $2 \%$ & $100 \%$ \\
\hline $\begin{array}{l}\text { SETTLING PONDS } \\
\text { CLEANING }\end{array}$ & 1 & $100 \%$ & \\
\hline TOTAL & 49 & & \\
SOUT: & & &
\end{tabular}

Source: The autores (2018).

It is possible to check a similar situation where the NAC's downstream is sprayed. However, the PLC and laboratory control system functions add up to a quantity of NACs whose representativity reaches $33 \%$ of the total NACs observed downstream in the system.

\subsubsection{Projection of maneuver margins for function with fault propagation potential}

The PLC control system function (Figure 7) is an industrial control and automation mechanism, commanded by the MX3000 software, developed by the HMA plant manufacturer. In the display of this mechanism, the operator can regulate the variables of the main production processes of HMA. In case any variable escapes from the control limits, the system issues an alert, causing the operator to seek to identify the cause of the variable out of control. Since the performance of a function may vary in precision and/or in time, a failure of the PLC command system communication to the other functions may lead to operational deviations due to inaccuracy in the transmission of the variables, as well as the delay in the response of the variable to the PLC communication.

The initial projection of maneuver margin, which allows the PLC control system to work with resources to cushion variabilities in the precision and time aspects would be the adoption of redundant devices. These devices are connected in parallel with the PLC, with both PLC and device outputs in parallel, should be equal. In case of failure of one signal, the other will be connected in parallel, ensuring accuracy in the transmission of commands. 
Although this solution brings to the operating system more robustness and consequently, resilience, it can also impact on the production costs.

Figure 7 - PLC control system function

\begin{tabular}{|c|c|}
\hline Name of function & PLC Command system \\
\hline Description & $\begin{array}{l}\text { The HMA plant is controlled by an automation system - MX } 3000 \text {, in which the } \\
\text { main operations of the HMA production process can be controlled. }\end{array}$ \\
\hline Aspect & Description of Aspect \\
\hline \multirow[t]{3}{*}{ Input } & Function driven by plant operator \\
\hline & $\begin{array}{l}\text { Laboratory uses moisture content to regulate the feeding conveyor productivity to } \\
\text { the drum dryer }\end{array}$ \\
\hline & Dynamic weighting is used to regulate the RPM of the $A C$ injection pump \\
\hline \multirow[t]{11}{*}{ Output } & Screw conveyor drive via PLC command \\
\hline & $\begin{array}{l}\text { Regulation of the RPM of the AC pump via the PLC control system, to reach a } \\
\text { certain AC content }\end{array}$ \\
\hline & Burner flame power regulation \\
\hline & Pressure regulation $\left(\mathrm{kgf} / \mathrm{cm}^{3}\right)$ of fuel supply and air \\
\hline & $\begin{array}{l}\text { Aggregates temperature control at the drum dryer outlet: optimum range between } \\
150^{\circ} \mathrm{C} \text { and } 155^{\circ} \mathrm{C}\end{array}$ \\
\hline & HMA temperature control in the mixer: optimum range from $160^{\circ} \mathrm{C}$ to $165^{\circ} \mathrm{C}$ \\
\hline & Temperature control in the bag filter: optimum range between $120^{\circ} \mathrm{C}$ and $150^{\circ} \mathrm{C}$ \\
\hline & Cold air lock actuator \\
\hline & Production records and productivity in tons of HMA \\
\hline & Variation of the fan rotation \\
\hline & $\begin{array}{l}\text { Control of the temperature of the asphalt cement optimum range between } 180^{\circ} \mathrm{C} \\
\text { and } 200^{\circ} \mathrm{C}\end{array}$ \\
\hline Precondition & Power supply via sensors \\
\hline \multirow[t]{2}{*}{ Resource } & MX3000 controller software system \\
\hline & Dynamic weighting is used to regulate the RPM of the AC injection pump \\
\hline \multicolumn{2}{|l|}{ Control } \\
\hline Time & \\
\hline
\end{tabular}

Source: The authors (2018). Produced with the FRAM Model Visualiser - version 0.4.1.

As an alternative to the adoption of redundancy devices in the PLC control system, a practice that is already performed and offers maneuver margins in case any problem occurs in the PLC, but at a low implementation cost, was verified in field observations. The practice consists in filling out on a daily basis, in the plant's production bulletins, the parameters used that day, shown by the PLC display. This practice allows that, in case of any problem that prevents the PLC from transmitting commands to the industrial equipment, it is possible to operate the equipment manually, regulating them based on the production bulletin notes of other days. In this bulletin there are fields to fill in information that are generated by the PLC control system, such as the injection content of the asphalt binder, productivity in tons/hour fed in the dryer and the synchronism with the dynamic balance of the conveyor belt, 
regulation and flow of the asphalt pump, and RPM of the conveyor belts of the different aggregate silos.

Although the items filled in by the plant operator guarantee the operation in case the PLC stops working, other outputs that have an impact on quality and environmental aspects could also be noted. These aspects are included in the PLC control system function mapping, and are: burner flame power regulation; pressure regulation $\left(\mathrm{kgf} / \mathrm{cm}^{3}\right)$ of fuel and air supply system; aggregates temperature control at the dryer outlet; asphalt cement temperature control; and bag filter temperature control. The registration of these items in the production bulletin also allows further analysis and studies on the general impact of production variables, as well as design practices of experiments, application of correlation tests and observation of the behavior patterns of the production system.

The laboratory control function (Figure 3) that added to the PLC command system function reaches a $33 \%$ representation, has as outputs of its performance, the decision making on the regulation of variables, based on the tests performed, and aiming at compliance with specifications of HMA projects. Variations in output, in the time aspect, reflect in slowness in decision making, which can delay necessary adjustments and compromise the quality of production. Output variations in the precision aspect compose errors and failures that will negatively impact the HMA specifications, which may lead to both waste of operational resources and non-conformity of the HMA with the project specifications. A solution for resilience, which is already practiced informally, is the construction of a table of templates for consultation, where there are parameters inherent to the variables tested. This template can be built empirically, because as the regulation of some variable is requested, the result must be retested, and registered the obtained variations, until the product presents conformity to the project. This type of action can be considered as a resource that enables maneuver margins within the laboratory control function, providing a source of consultation for faster and more accurate responses to variations perceived in the process. Table 8 is registered, summarizing the functions with failure propagation potential - where one with technological factor was evidenced, the other with human variability factor. 
Table 8 - Variability analysis in downstream functions

\begin{tabular}{l|l|l|l} 
FUNCTION & POTENTIAL & FACTOR & \multicolumn{1}{c}{ VARIABILITY ANALYSIS } \\
\hline PLC Controller & Fault propagation & Technological & $\begin{array}{l}\text { The PLC controls practically all the system's mechanical } \\
\text { variables, that is, a programming error can possibly } \\
\text { spread collapsing the system. For these cases, the } \\
\text { organization must evaluate whether it pays off to have a } \\
\text { second system acting in redundancy, alerting the } \\
\text { operator if there is a data loop failure. }\end{array}$ \\
\hline $\begin{array}{l}\text { Laboratory } \\
\text { Control }\end{array}$ & Fault propagation & Human & $\begin{array}{l}\text { Human functions may present variability due to pressure } \\
\text { for productivity or achievement of cost targets. As the } \\
\text { laboratory control deals with several resources for } \\
\text { decision making, it is suggested to use gauge tables to } \\
\text { help in moments of pressure in which tests present } \\
\text { dispersed results, demanding special care. }\end{array}$
\end{tabular}

Source: The author (2018).

\section{DISCUSSION}

Proposals of maneuver margins for the functions with the greatest homeostatic potential and fault propagation were shown to the group of experts who were interviewed. The objectives of this presentation, besides passing on the improvement proposals, was to discuss how they understood the result of the case study, and confirmed the characteristics pointed out in the mapping and validating the research. The understanding the identified functions can bring more stability to the system, with investment and improvements, was unanimous, as well as, the proposed maneuver margins, some of them that are already applied and were observed in this research, tend to bring more uniformity in results in the aspects of quality, costs and safety of the system. This validation corroborates the premise of this article, that the identification of functions of homeostatic potential and fault propagation enable applications of resilience engineering.

The FRAM methodology was able to perform a systemic mapping of a production process, eliciting the most representative functions and opening the scope of its aspects, describing them for a better understanding of what is necessary for the system to work. By counting the NAC's of each function, the functions with the greatest potential for variability are classified, thus allowing resources to be invested in those functions that will have the greatest impact on the process. Thus, an answer to the research question proposed at the 
beginning of the article, on how to use resilience engineering, in the FRAM tool, for fault propagation mitigation in a productive socio-technical system.

As for the analysis of the functions with higher variability potential, it is perceived adequate the framing of purposeful measures in the issues of stability and safety of the production process, based on the four pillars of RE, to quote, monitoring, anticipation, response and learning. The principle of FRAM is precisely to understand how a failure in a variable may not be well received by the next stage of a process, generating reverberations and contaminating the system with emerging failures, until causing a collapse event, as in extreme cases, accidents of great magnitude. At this point the synergy with the monitoring and anticipation of variable behavior is verified, as well as being prepared and knowing which resources and controls can be used to respond correctly without impacting the results of the processes. Learning is the pillar that structures all the others, giving conditions for the system and its operators to become increasingly robust and resilient.

It is not the intention of this article to exhaust the alternatives, or to delimit the absolute truth about the paths to apply RE. As Almeida (2008), Hollnagel et al. (2014), Alvarenga et al. (2014), Fogaça (2015) and Wachs (2016) cite, FRAM is an open methodology that allows the modeling of productive systems and the observation of nonlinear work flows, with enough scope to be analyzed from different perspectives. Besides the approach adopted in this case study, FRAM can address the issue of function types, classifying the types into human, technological and organizational. In terms of fault propagation in output aspects, the classification of variability as time or precision can be used, besides its graduation.

As a graphical tool, FRAM also has great applicability, because it allows to quickly check which functions, and how they are impacted if any problem occurs during the process. However, especially in modeling with a large number of functions and aspects, the graphic model ends up being somewhat confusing, requiring the use of software to be better shown, which highlights the connections made by the functions when selected, facilitating the understanding of workflow analysis. Thus, it is necessary to say that the graphical representation of FRAM is not friendly at first sight, requiring training and study to be more easily understood. 


\section{CONCLUSION}

Socio-technical systems are those where people and technologies interact intensely, often under various kinds of pressures, such as organizational, governmental, societal, functional and even trade union; these pressures generate conflicting goals, increasing the work procedures, demanding more performance at lower cost and raising security protocols. As one said, the rope breaks on the weaker side - operators, of course with all human qualities, have to deal with an ever-increasing number of variables. In this context, the study of productive systems with bias in the variability of their functions becomes so important, because it is a way to mitigate risks and provide a more stable and safer system both in terms of result and health for professionals.

From a theoretical point of view, this article leaves as a legacy for future research, a method for the identification of homeostatic functions and fault propagation that can be replicated for other productive socio-technical systems. In ideal situations, all functions should have resources for maneuver margins and thus ensure the system's resilience to the phenomena of variability in processes, for economic and technical reasons often this is not possible to achieve. A path to be adopted for the identification of the functions has been demonstrated, as well as an analysis under the light of resilience engineering to increase the robustness of the system. The modeling of the system in FRAM also allows suggesting other types of studies, such as risk management analysis, since the more upstream aspects a function presents, the lower is the probability of an aspect with unexpected variability impacting the system. The capture of mental models of different operators on a productive system also becomes possible, applying the interview with the elicitation of the aspects of the functions, and later counting the number of aspects reported by each operator. It is also possible to evaluate the workflow in the system, by how many aspects each function group presents, balancing the number of aspects in order to avoid that certain functions deal with many aspects, while others deal with fewer aspects.

From the organizations point of view, a manager can set up an analysis of his productive system based on the methodology presented in this article, thus being able to explore it as training for his operators, as well as identify stages of his processes that need more robustness to avoid failures and accidents. 


\section{References}

ALMEIDA, I. M. Análise de barreiras e o modelo de ressonância funcional de acidentes de Erik Hollnagel. Department of Public Health of Medical College of Botucatu. São Paulo, 2008. Available at: http://www.scielo.br/pdf/rbso/v33n118/03.pdf. Access on April 15, 2018.

ALVARENGA, M. A. B.; FRUTUOSO E MELO, P. F.; FONSECA, R. A. A critical review of methods and models for evaluating organizational factor in human reliability analysis. Rio de Janeiro. Elsevier, 2014. Available at: https://www.sciencedirect.com/science/article/pii/S0149197014000936. Access on May 19, 2018.

DEKKER, S. Drift into failure: from hunting broken components to understanding complex systems. Ashgate, Burlington, 2011. Available at: https://epdf.tips/queue/drift-into-failurefrom-hunting-broken-components-to-understanding-complex-syste.html. Access on: May 16, 2018 .

DEKKER, S. Failure to adapt or adaptations that fail: contrasting models on procedures and safety. Applied Ergonomics, Linköping Institute of Technology. Linköping, Suécia, 2003. Available

http://citeseerx.ist.psu.edu/viewdoc/download?doi=10.1.1.606.3361\&rep=rep1\&type=pdf.

Acess on: April 19, 2018.

FOGAÇA, L., B.; Tomada de decisão e equilíbrio de metas conflitantes no gerenciamento de interrupções de voo em empresa de transporte aéreo regular. PUC, Porto Alegre, 2015. Available at: http://hdl.handle.net/10923/7094. Acess on: April 20, 2018.

HOLLNAGEL, E.; PRUCHNICKI, S.; WOLTJER, R., et al. Analysis of Comair flight 5191 with the functional resonance accident model. In: INTERNATIONAL SYMPOSIUM OF THE AUSTRALIAN AVIATION PSYCHOLOGY ASSOCIATION. $8^{\text {th }} .2008$. Available at: https://hal.archives-ouvertes.fr/hal-00614254. Acess at: April 15, 2018.

HOLLNAGEL, E. FRAM: the Funcional Ressonance Analysis Method - modelling complex socio-technical systems. Burlington: Ashgate. 2012.

HOLLNAGEL, E. Human factors/ergonomics as a systems discipline? The human use of human beings. Denmark. Elsevier, 2014. Available at: https://www.sciencedirect.com/science/article/pii/S0003687013000653. Access on: April 19, 2018

HOLlNAGEL, E.; HOUNSGAARD, J.; COLligAn, L. FRAM - The Functional Ressonance Analysus Method - a handbook for the practical use of the method. Middelfat, Denmark. Centre for Quality, 2014. Available at: http://functionalressonance.com/how-tobuild-a-fram-model/fram-handbook.html. Acess on: April 19, 2018. 
HOSSEINI, S.; BARKER, K.; RAMIREZ-MARQUEZ, J. E. A review of definitions and measures of system resilience. Reliability Engineering and System Safety, v. 145, p. 47-61, 2016.

JURAN, J. M. A qualidade desde o projeto: novos passos para o planejamento da qualidade em produtos e serviços. 10 ed. São Paulo: Cengage Learning, 2011.

KOSKELA, L. Application of the New Production Philosophy to Construction. Technical report, Finland: CIFE, 1992. Available at: http://leanconstruction.wordpress.com/downloads. Acess on: April 11, 2018.

LEVESON, N. A new accident model for engineering safer systems. Cambridge, US, Massachusetts Institute of Technology, 2004. Available at: http://sunnyday.mit.edu/accidents/safetyscience-single.pdf. Acess on: April 16, 2018.

PORTELA, J. C. Abordagens de segurança operacional da Usina Hidroelétrica Itaipú Binacional sob perspectiva da engenharia de resiliência. UFRGS, Porto Alegre, 2016. Available at: http://www.lume.ufrgs.br/handle/10183/156818. Acess at: April 20, 2018.

RASMUSSEN, J. Risk management in a dynamic Society: a modelling problem. Smorum, Dinamarca. $\quad$ Elsevier $\quad$ Science, $1997 . \quad$ Available at: http://lewebpedagogique.com/audevillemain/files/2014/12/maint-Rasmus-1997.pdf. Acess o n: May 05, 2018.

RIGHI, A. W. Caracterização e análise da complexidade como recurso para gestão de sistema sócio técnicos. UFRGS, Porto Alegre, 2014. Available at: http://www.luma.ufrgs.br/handle/10183/105013. Acess on : April 18, 2018.

RIGHI, A. W.; SAURIN, T. A. Engenharia de resiliência: um panorama de seus estudos e perspectivas de pesquisas futuras. Brazilian Association of Production Engineering. In: NATIONAL MEETING OF PRODUCTION ENGINEERING, 31th, 2011. Anais... ABEPRO, Belo Horizonte, MG, 2011.

TAGUCHI, G. Introduction to quality engineering: Designing quality into products and processes. Dearborn: Asian Productivity Organization; 1986.

VARGAS C. V.; GUIMARÃES, L. B. M. A Engenharia de Resiliência e o Sistema de Controle de Tráfego Aéreo. Brazilian Association of Production Engineering. In: NATIONAL MEETING OF PRODUCTION ENGINEERING，26th，2006. Anais... ABEPRO, Fortaleza, CE, 2006.

WACHS, Priscila. Modelo para Integração entre melhorias de procedimentos operacionais padronizados e capacitação de operadores de sistemas sociotécnicos complexos. UFRGS, Porto Alegre, 2016. Available at: http://lume.ufrgs.br/handle/10183/156475. Access on: April 18, 2018. 
WOLTJER, R.; HOLLNAGEL, E. Functional modeling for risk assessment of automation in a changing air traffic management environment. International Conference Working on Safety, Creta, 2008. Available at: https://www.researchgate.net/publication/237088888_Functional_modeling_for_risk_assessm ent_of_automation_in_a_changing_air_traffic_management_environment. Acess at: May 18, 2018 .

Woo, D. M.; VICENTE, K. J. Sociotechnical systems, risk management and publig health: comparing the North Battleford and Walkerton outbreaks. Reliability Engineering and System Safety, v. 80, p. 253-269, 2003.

Appendix A - Semi-structured FRAM based interview script:

1. Description: age, function experience time, formation.

Contextualize the operator interviewed in the productive system.

2. General description of the activities: talk about the production process of CBUQ, contemplating from the reception of the demand to the loading of the asphalt mix in the truck. What are the main activities performed?

Identifying the main activities/functions existing in the productive process.

3. Questions for functional mapping - FRAM:

a) How and when do you start this activity? What are the "signs" for its start? Determine which data and events are necessary for the function to start (input aspect).

b) What tools or resources do you use to perform this activity? How did you learn / clarify questions about how to use these resources? And what to do in the absence of these resources?

Determine and describe which resources are used to perform the function, as well as what to do in case of unavailability.

c) Are there any procedures or rules that need to be followed for the activity to run smoothly? For example, checklists, standard operating procedures, flow charts, and so on.

Determine the existence of preconditions for the performance of the function.

d) How does the pressure for time affect the activity performance?

Determine how the time aspect influences the function performance. 
e) What is the activity optimal performance? How are you charged for this performance? Determine how the control of the described function is performed.

f) What is the activity result? What are the requirements for the next step to be able to perform your own activities correctly?

Describe what are the outputs of the function.

4. If it were possible to characterize the main factors involved in the performance of this activity, among aspects such as costs, security, quality and environment, how would you do it?

Categorize the functions described above among the factors mentioned. 